JOURNAL OF CORPORATE RESPONSIBILITY

AND LEADERSHIP

CONTEMPORARY Issues IN CORPORATE SOCIAL ReSPONSIBILITY

\title{
Corporate benefits of CSR activities
}

DOI: http://dx.doi.org/10.12775/JCRL.2014.006

\author{
MAJA ŻYCHLEWICZ \\ a The Faculty of Economic Sciences and Management, \\ Nicolaus Copernicus University, Toruń, Poland \\ e-mail: majazychlewicz@onet.pl
}

\begin{abstract}
The main aim of the paper is to present the benefits that a company may derive from socially responsible activities. The paper lists various definitions of CSR that indicate the expected benefits stemming from its use. Both in theory and in practice, there is observed the need for strategic connection between the CSR concept and its real-life benefits.
\end{abstract}

Keywords: essence of CSR, strategic CSR, benefits from implementation of CSR, CSR instruments, company goals.

\section{Introduction}

In the old days, success of a company was based mostly on quality and usefulness of offered products. At present, these factors are still important, however globalization has changed the realities of the economy. Today, apart from product quality, companies are also judged according to their image. Therefore, an increasing role is played by corporate social responsibility (Bieńkiewicz, 2008, p. 10).

As observed by Wierciński (2011, p. 57) the literature lacks a uniform approach to what exactly constitutes socially responsible activities. Therefore, both Polish and foreign sources have been surveyed in order to identify various perspectives and to point out how to achieve tangible and intangible benefits from the CSR concept implementation. 
The main aim of the paper is to present the benefits that a company may derive from socially responsible activities. It has been achieved by the analysis of data from questionnaire surveys, case-studies and interviews available in subject literature and electronic sources.

The structure of the paper reflects the research goals. First of all, presented is the variety of literature approaches to gaining benefits from CSR, which highlights the importance of a self-interest approach to pro-societal activities. Secondly, presented are benefits that a company may reap from CSR activities, which are supplemented by the examples from the business practice. The paper's structure also allows to achieve the second operational objective, i.e. presentation of CSR instruments that enable a company to achieve said benefits. What is more, the analysis of corporate benefits results in an important conclusion that all positive results of strategic CSR implementation lead, due to their interdependencies, to increase in the company financial gains.

\section{Attitudes towards benefits from CSR in literature}

The authors' attitudes towards gaining benefits from CSR activities, which can be identified in the literature, are not uniform and they stem from different approaches (cf. Figure 1) to define corporate social responsibility (Zboroń, 2011, p. 32).

\section{Figure 1 \\ Attitudes towards \\ benefits \\ from CSR \\ Source: Own \\ deliberation on the \\ basis of: Zboroń, 2011, p. 32.}

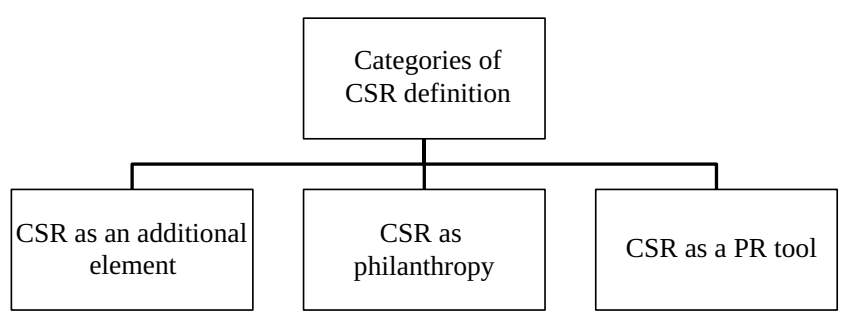

The first approach does not take into consideration the necessity of socially responsible practices. The advocates of this theory assume that the main objective of an enterprise is to increase its profits (Ostrowska, 2013, p. 96). The characteristic facet of such an attitude towards CSR is considering it as a set of activities that frequently translate to significant 
financial losses. The followers of this approach seem not to notice the potential benefits of socially responsible business (Nowak, 2011). Such an approach to the issue of corporate social responsibility is represented among others by Friedman (1997).

The second definition presents company social responsibility in a much broader sense. The proponents of this theory preach selflessness of activities undertaken under the auspices of corporate social responsibility. They see socially responsible actions as a need of heart and a societal obligation (Stefańska, 2011, p. 304). It should be emphasised that people choosing this approach engage in CSR activities without thinking of possible financial benefits.

The last approach considers social responsibility as a PR tool. It assumes that actions undertaken are socially responsible but they are expected to provide a return on investment and, in result, an increase in profits. The representatives of this approach perceive CSR as a source of financial and image gains (Stefańska, 2011, p. 304).

As highlighted by Forum Odpowiedzialnego Biznesu (Responsible Business Forum) such a notion of social responsibility is erroneous, because "CSR is a responsible way of operating in a given social, economic, natural environment context while Public Relations encompass strategies aimed at providing information, persuading proposed solutions and building a climate of acceptance for the company's actions, i.e. actions in support of building reputation and creating the company image" (FOB, 2014).

The author cannot agree to the full extent with any of the aforementioned approaches. It seems that corporate social responsibility should be viewed from the perspective of strategic management. In this context, the implementation of socially responsible solutions is not a random promotional campaign, philanthropy, or a tool that generates losses for the company. From the strategic perspective, CSR is a well-considered strategy combining conscious sharing of company resources and achieving tangible and intangible benefits (cf. Dębski, 2009).

This approach to CSR enables a company to calculate the costs of pro-social undertakings and to predict the returns and factors that contribute to the goal achievement (Pienias, 2013, p. 85). In this view, CSR is an effective strategy that, via social dialogue on a local level, results in increased competitiveness of a company on the global level (Jastrzębska, 2011, p. 97). Corporate social responsibility understood in this way means achieving financial success in a way that takes into 
consideration ethical values, employee rights, development of communities and protection of the natural environment (Nakonieczna, 2008, p. 20).

\section{Benefits from CSR activities}

The analysis of benefits resulting from the strategic use of CSR should be preceded by defining what CSR benefits are. According to Lewicka-Strzałecka (2005, p. 15) CSR benefits should be understood as providing financial gains to the owners of the company and undertaking pro-societal initiatives at the same time. Therefore, we should assume that benefits for an organisation consist of measurable gains that results from the strategy of the said organisation as well as its societal results (Bartkowiak, 2011, p. 77). The benefits from CSR may be achieved via the implementation of strategic actions related to social responsibility. The strategy should take into account the needs of the company itself as well as its internal and external stakeholders. Defining business goals and supporting them social and ecological goals is an important aspect of developing such a strategy (Bieńkiewicz, 2008, p. 13).

Creating a positive image of the company is often enumerated among the benefits of CSR strategy implementation. Here we should present the results of the study on the assessment of CSR standards' implementation conducted by PART in 2011. According to the findings, the benefits from CSR initiatives with no regard to its own participation are indicated by $60 \%$ surveyed companies. Over a half, i.e. $74 \%$ of respondents confirmed that they observed the strengthening of the positive company image as a consequence of CSR undertakings (PARP, 2011, p. 4).

The CSR initiatives that support the positive corporate image include, among other things, the company involvement in ecological issues. Showing care and interest into the natural environment protection builds the image of a company taking responsibility for its impact on the environment (Rogowski, Korpus and Deluga, 2011, p. 55).

Activities toward environmental protection should be undertaken by companies at all operating stages. Starting with the supply department, here the actions can be focused on: acquisition of resources and semi-final products manufactured in a sustainable way, or elimination of components or substances harmful to human health. During the production and packaging, the management should focus on, among other things: 
reduction of water use, noise or emission of harmful substances, proper waste management, and matters related to $\mathrm{OH} \& \mathrm{~S}$. Storage and transport stages also provide a broad array of opportunities to mitigate the negative environmental impact. Here the list contains, among others: choice of transport means characterized by limited emission of greenhouse gasses, optimization of storage space, elimination of losses and waste produced during long-term storage (Ratajczak, 2010).

Reporting the company's activities is an important aspect of positive image creation by pro-ecological actions. A good example here is "Przegląd CSR" issued by Danone. The company uses the document to present the ever decreasing use of water and energy as well as falling quantities of waste created, making the information available to interested readers. Another company that informs the world of its pro-environmental activities and thus builds its positive image is Lotos. In the Social Responsibility Report for 2006-2007 the company lists all the environmental data in accordance with the Global Reporting Initiative (Zachowicz, 2009, p. 1).

The interventions of BP company may be one of the examples of CSR activities undertaken in face of the crisis, when such undertakings seem the only way to rebuild the image of a company, not to mention investor and client trust. When faced with the oil rig disaster in 2010 the company created the "Crisis Management Center" to control undertaken actions which resulted in stopping the plummeting worth of company's shares. In order to repair its image, BP has spent 500 million USD to independently investigate the impact of the spill on the maritime environment in a study to last 10 years. Furthermore, the company hailed that net income from the sale of oil from the damaged rig would be used to create a wildlife protection fund (Employer Branding Club, 2012, p. 1).

Social campaigns are another tool in the CSR arsenal that is used to shape the corporate image. This tool requires a company to involve itself in a campaign that addresses a certain social problem, and which aims to change the attitudes of a given social group (Dobek-Ostrowska, 2007, p. 26). A interesting example is a social Polish campaign "Płytka wyobraźnia to kalectwo" ("Shallow imagination means disability"). The campaign aim is to protect the youth against jumping into water of unknown depth which in many cases results in disability or even death.

What is more, it should be noted that pro-environmental actions, apart from image gains, improved relationships with surrounding 
environment, local societies, and public sector, help to generate savings and increase profits (Paliwoda-Motylińska, 2009, p. 153).

Cost reductions are also possible to be achieved by socially responsible human resources management. This aim may be reached by ensuring occupational health and safety, work hygiene and providing employees with learning and development opportunities, as well as providing medical benefits to employees and their families. These activities also increase work efficiency and decrease personnel rotation. A significant role is played by implementation of work safety rules not required by the law in force, e.g. different forms of employee benefits. A prime example of that is ARGUS Group where the work absence indicator fell to $4 \%$ when employees had been provided with healthcare packages (Greszta, 2009, p. 46.)

Unilever is listed among the companies that effectively apply the corporate social responsibility concept to generate financial gains. This international production company is able to achieve astounding savings due to undertaken CSR activities. Between 1996-2001 the savings amounted to 1.5 million USD due to decreased use of energy, water and reduction of waste. Furthermore the return on that investment amounted to $1000 \%$ (Mazur-Wierzbicka, 2012, p. 50).

Increased revenue is another gain to be achieved by a company via social responsibility. In many cases this gain is realized when "green" products are introduced on the market. Eco-products attract new buyers and increase brand loyalty. One of examples may be introduction of “eco car batteries” by Petronii (Grzeszta, 2009, p. 45). This move resulted in a new group of clients, and the company maintains its ecological commitment by other pro-environmental actions such as collection of old batteries.

Another significant gain from CSR is an increased customer loyalty and the possibility of attracting new clients (Kucharski, 2005, p. 2). Eco-labelling and social-labelling of products are CSR tools that strongly influence loyalty and attraction levels (Koszewska, 2011, p. 193). Their idea is to provide product labels and packaging with information on undertaken socially responsible actions. The information may relate to many different areas of life, such as (Łukasiewicz-Kamińska, 2011, p. 33):

- care for the environment, packaging from recycled materials, limited use of natural resources, reduction in harmful substances during the production process; 
- animal rights, no animal testing;

- employee care, corporate ethics code;

- human rights;

- supplier care via timely payments.

This instrument provides current and potential clients with information that strongly influences their consumer attitudes. A client who is aware of the socially responsible character of company's undertakings gains trust and informs his or her surroundings about such initiatives.

Strengthening customer loyalty and attracting new buyers is also possible via socially involved marketing (Łukasiewicz-Kamińska, 2011, p. 30). This tool is based on performing business activities in cooperation with non-governmental organisations (Karwacka, 2011, p. 133). Such a partnership is mutually beneficial. However, it must be noted that in extreme cases Customer Relationship Management activities may be perceived negatively. One of reasons for such an assumption may be the fact that the environment perceives a given program only through its financial aspect. This results in a situation that is highly harmful to both parties. In such a case, both entities suffer damage to their respective images.

Mitigation of business risk is considered to be another significant gain from CSR. This aim may be achieved by maintaining dialogue with the company's stakeholders. Gathering information concerning expectations of: clients, suppliers, business partners and proper management of such knowledge is an effective tool to reduce business risk. The partnership between British Sainsbury and Greenpeace may be listed among the examples of such cooperation. Exchange of experience between the entities helped the company to avoid protests organised by ecological activists against the methods of acquiring fish products (Grzeszta, 2009, p. 46).

Dialogue with business partners increases their trust which results in higher willingness to provide credit and reduce business risk. This aspect may be especially important for newly-established companies, that seek external funding to develop themselves. Banco Cuscatlan is a good example of a company which became the industry leader by building positive relations with financial partners (Grzeszta, 2009, p. 50).

Moreover, increased competitiveness of the company is another gain from CSR. Stakeholders are characterized by increasing demands toward organisations and they have a growing impact on these 
organisations. The companies are expected to bear costs of damage caused by their business activities. These entities who wish to maintain their competitive advantage should adapt to the changing demands of the environment in which they operate. What is more, it should be noted that due to the process of globalisation, the consumer awareness increases in relation to working conditions in today's companies, which forces the businesses to apply for the "responsible company" label (Wołkowicka, Dąbrowski, 2012, p. 5). Therefore, it is justified to assume that in contemporary business conditions, applying CSR is a prerequisite of building sustainable competitive advantage.

Increased satisfaction, involvement and motivation of employees and their increased identification with the company may be achieved by responsible human resources management. The examples of pro-societal activities in this area include: development and increasing qualifications of employees, involvement of subordinates in the decision-making process, fair payment, providing employees with support to effectively manage the life/work balance (Mazur-Wierzbicka, 2012, p. 37). Additional motivation is also generated by ethical programmes towards employees concerning ethics, special procedures when the said ethics are breached, or establishing a special Ethics Representative in a company.

According to Łukasiewicz-Kamińska, the code of ethics is the most effective element of ethics programmes, as far as employee motivation is concerned. Such a code is a documented listing of values and regulations that is pledged by signatures of both the workers and the management (Kowalczyk, 2009, p. 19). Furthermore, codes of ethics reduce the number of instances of lying, corruption, fraud and other bad practices, they help to limit the possibility of conflicts of interests, increase reliability of personnel and employee loyalty (Łukasiewicz-Kamińska, 2011, p. 34). Establishing of a code of ethics improves the company organisational culture.

A company that is socially responsible by being able to adapt to changes is also an innovative company. In this respect, innovativeness is understood as taking into consideration the interests of all the parties and following the zeitgeist of globalisation. 


\section{Summary}

It is common knowledge that profit is the ultimate goal of every company. This fact is exemplified even in the sole definition of what a company is. However, it is worth noting that this goal may be achieved by a number of means. Some entities are driven to maximise their profits no matter their impact on the environment. There are other companies where emphasis is laid on compensation of losses caused in the society and the environment. However, Freedman is of opinion that even the most self-centred entrepreneurs driven solely by profit have, eventually, positive impact on the social welfare (Freedman, 1997, p. 57).

Financial gains have been found to be the most crucial factor in the analysis of benefits derived from CSR. Many different CSR-derived values have been identified but every single one translates into increased profits. It should be noted that gains from socially responsible activities are beneficial to companies in two ways, as tangible and intangible gains.

The tangible gains are: reduction of costs, profit making and financial deductions due to pro-societal activities. It must be emphasized that these benefits directly result in the increase in profits. The intangible values include, among others: increased competitiveness, building company reputation and positive image, i.e. possibility of acquiring new clients. These types of benefits are also ultimately translated into higher corporate profits.

Therefore, it can be argued that CSR impacts the gains of the company in both direct and indirect manner. An important conclusion is that only strategic CSR may influence the level of profits. Calculation of achieved benefits is possible by analysing the profitability of actions undertaken in relation to a given strategy. The starting point is to define what exactly was expected from the company strategy and to compare potential gains with the actual gains.

Nevertheless, in many cases it happens that strategic responsible management is treated as an activity somewhat separated from business practice. This is an erroneous way of thinking and is doomed to fail. In a socially responsible organisation, the real value may only be achieved when the following foundations are established: solid procedures, efficiency indicators and integration of goals of the responsible business with the basic area of company's competence. 
Properly implemented CSR is an exemplary win-win situation. It means that both interested parties achieve actual gains. As Bieńkiewicz, (2008, p. 10) highlights: "On one side, the awareness of the significance of positive relationships of a company with other entities in its internal and external environment may become a foundation for pressure on solutions beneficial for the said groups; on the other side - skilful planning of strategic CSR activities is a useful tool for a company to achieve actual impact on its environment”.

\section{Bibliography}

Bartkowiak, G. (2011), Społeczna odpowiedzialność biznesu w aspekcie teoretycznym i empirycznym, Difin, Warszawa.

Bieńkiewicz, M. (2008), “Społeczna odpowiedzialność biznesu (CSR) jako narzędzie budowy przewagi konkurencyjnej przedsiębiorstw”, Working Paper, Vol. 2.

Dębski, Ł. (2009), “Społeczna odpowiedzialność przedsiębiorstw w Unii Europejskiej”, available at: www.twojaeuropa.pl/423/spoleczna-odpowiedzialnosc-przedsiebiorstwa-w-unii-europejskiej, (accessed 15 February 2014).

Dobek-Ostrowska, B. (2007), Komunikowanie polityczne i publiczne, PWN, Warszawa.

Employer Branding Club (2011), “CSR a Employer Branding na przykładzie BP”, available at: www.employerbrandingclub.com/csr-a-employer-branding-naprzykladzie-bp.html (accessed 14 July 2013).

FOB (2014), “Encyklopedia CSR”, available at: www.odpowiedzialnybiznes.pl//pl/ baza-wiedzy/o-csr/co-to-jest-csr.html (accessed 25 January 2014).

Nowak, J. (2011), "Wpływ CSR na konkurencyjność małych i średnich firm. Mali, ale odpowiedzialni - przykłady dobrych praktyk w sektorze MŚP regionu śląskiego”, available at: www.odpowiedzialnybiznes.pl/artykuly/wplyw-csr-na-konkurencyjnosc-malych-i-srednich-firm-mali-ale-odpowiedzialni-przyklady-dobrych-praktykw-sektorze-msp-regionu-slaskiego/ (accessed 12 September 2014).

Friedman, M. (1997), “Społeczną powinnością biznesu jest pomnażanie zysków”, in: Ryan, L.V., Sójka, J. (Eds.), Etyka biznesu: Z klasyki amerykańskiej, W drodze, Poznań.

Greszta, M. (2009), “Sześć kluczowych korzyści wynikających z zaangażowania firmy w ideę zrównoważonego rozwoju”, available at: www.csrconsulting.pl/docs/zasobnik_plik_20110119214107_607.pdf (accessed 10 July 2013).

Jastrzębska, E. (2011), “System społecznej odpowiedzialności warunkiem skutecznego wdrażania koncepcji CSR”, in: Karaszewski, R., Karwacka, M., Paluszek, A. (Eds.), Społeczna odpowiedzialność biznesu: Perspektywy i kierunki rozwoju, Wydawnictwo Uniwersytetu Mikołaja Kopernika, Toruń, pp. 95-121.

Karwacka, M. (2011), "Realizowanie społecznej odpowiedzialności biznesu przez partnerstwa przedsiębiorstw i NGO’s”, in: Karaszewski, R., Karwacka, M., Paluszek, A. (Eds.), Społeczna odpowiedzialność biznesu: Perspektywy i kierunki rozwoju, Wydawnictwo Uniwersytetu Mikołaja Kopernika, Toruń, pp. 133-151. 
Koszewska, M. (2011), “Normy i standard w obszarze CSR jako istotny czynnik determinujący zachowania nabywcze konsumentów”, in: Karaszewski, R., Karwacka, M., Paluszek A. (Eds.), Społeczna odpowiedzialność biznesu: Perspektywy i kierunki rozwoju, Wydawnictwo Uniwersytetu Mikołaja Kopernika, Toruń, pp. 193-223.

Kowalczyk, J. (2009), Odpowiedzialność społeczna i przeciwdziałanie korupcji w zarzq̨dzaniu organizacjq, CeDeWu, Warszawa.

Kucharski, M. (2005), "Rola i znaczenie koncepcji społecznej odpowiedzialności biznesu”, available at: www.proto.pl/PR/Pdf/Rola_i_znaczenie_MKucharski.pdf (accessed 13 September 2014).

Lewicka-Strzałecka, A. (2006), Odpowiedzialność moralna w życiu gospodarczym, IFiS PAN, Warszawa.

Łukasiewicz-Kamińska, A. (2011), Społeczna odpowiedzialność przedsiębiorstwa finansowego, Difin, Warszawa.

Mazur-Wierzbicka, E. (2012), CSR w dydaktyce czyli jak uczyć studentów społecznej odpowiedzialności, Stowarzyszenie Kreatywni dla Szczecina, Szczecin.

Nakonieczna, J. (2011), Społeczna odpowiedzialność przedsiębiorstw międzynarodowych, Difin, Warszawa.

Paliwoda-Matiolańska, A., (2009), Odpowiedzialność społeczna w procesie zarzq̨dzania przedsiębiorstwem, C.H. Beck, Warszawa.

PARP, “Cała prawda o polskim CSR”, available at: www.prasa.parp.gov.pl/index/ more/25838 (accessed 14 July 2013).

Pienias, A. (2013), “CSR Społeczna odpowiedzialność biznesu w Polsce”, in: Krzysztofek A. (Ed.), Zarzq̨dzanie i rozwój regionalny - wyzwania współczesności, ATW, Kraków, pp. 85-93.

Rabiański, R. (2013), “Działania i korzyści związane z CSR”, available at: www.elemenatrzbiznesu.pl (accessed 10 July 2013).

Ratajczak, M. (2010), “Implementacja strategii CSR w odniesieniu do środowiska naturalnego jako ważny element strategii rozwojowych współczesnych przedsiębiorstw”, Zeszyty Naukowe SGGW w Warszawie - Problemy Rolnictwa Światowego, Vol. 10, pp. 74-81. available at: www.wne.sggw.pl/czasopisma/pdf/ PRS_2010_T10\%2825\%29_z4_s74.pdf (accessed 12 September 2014).

Rogowski, W., Korpus, J., Deluga, K. (2011), “Wybrane przykłady wdrażania strategii społecznej odpowiedzialności przedsiębiorstw działających w Polsce”, in: Karaszewski R., Karwacka M., Paluszek A. (Eds.), Społeczna odpowiedzialność biznesu: Perspektywy i kierunki rozwoju, Wydawnictwo Naukowe Uniwersytetu Mikołaja Kopernika, Toruń, p. 55-73.

Stefańska, M., (2011), “CSR a wartość przedsiębiorstwa”, in: Pisz, Z., Rojek-Nowosielska, M. (Eds.), Społeczna odpowiedzialność organizacji: Polityczna poprawność czy obywatelska postawa? Wydawnictwo Uniwersytetu Ekonomicznego we Wrocławiu, Wrocław, pp. 415-430.

Ostrowska, M. (2013), “Społeczna odpowiedzialność przedsiębiorstw CSR - zbędny koszt czy dobra inwestycja?”, in: Krzysztofek A. (Ed.), Zarzq̨dzanie i rozwój regionalny - wyzwania współczesności, ATW, Kraków, pp. 93-101.

Wierciński, Sz. (2011), “CSR jako przedsięwzięcie biznesowe”, Master of Business Administration, No. 2, pp. 54-67. 
Wołkowicka, A., Dąbrowski S., "Społeczna odpowiedzialność biznesu a konkurencyjność przedsiębiorstwa”, Studia i Prace Wydzialu Nauk Ekonomicznych i Zarzq̨dzania Uniwersyetu Szczecińskiego, No. 30, pp. 79-89. available at: http://www.wneiz. pl/nauka_wneiz/sip/sip30-2012/SiP-30-79.pdf (accessed 13 September 2014).

Zachowicz, R. (2009), “Kolejny raport CSR Lotosu” available at: www.m.odpowiedzialny.lotos.pl/1058/p,235,n,2895/aktualnosci/kolejny_raport_csr_lotos-u (accessed 25 July 2013).

Zboroń, H., (2011), “Dyskurs o społecznej odpowiedzialności ekonomistów (z kryzysem w tle)”, in: Pisz, Z., Rojek-Nowosielska M. (Eds.), Społeczna odpowiedzialność organizacji: Polityczna poprawność czy obywatelska postawa?, Wydawnictwo Uniwersytetu Ekonomicznego we Wrocławiu, Wrocław, pp. 15-30. 